\title{
LABOUR MARKET IN BRAZILIAN METROPOLITAN AREAS
}

\author{
mercado de trabalho nas Regiões Metropolitanas Brasileiras
}

\author{
Luís Abel da Silva Filho* \\ Silvana Nunes de Queiroz ** \\ Maria do Livramento Miranda Clementino ***
}

\begin{abstract}
Resumo
Este artigo tem como proposta central de investigação, fazer uma análise da participação feminina no mercado de trabalho no Brasil metropolitano. Os dados são da Pesquisa Nacional por Amostra de Domicílios (PNAD) e foram analisados no recorte que compreende os anos de 2001 e 2008. As principais estatísticas evidenciaram a elevação da participação feminina no mercado de trabalho com maior incidência na População Economicamente Ativa (PEA) nos anos em análise. Além disso, a taxa de desemprego feminino reduziu-se em quase todas as áreas metropolitanas brasileiras, mediante a elevação na taxa de ocupação. Todavia, elas são minoria no mercado formal de trabalho, quando comparado aos homens, dado pela elevada participação de ocupadas sem registro em carteira. Adicionalmente, ainda são minorias nas ocupações de maior projeção social, mesmo diante de um contexto de elevação da participação relativa ao longo dos anos. Já nas ocupações de menor projeção social elas são maioria em todas as regiões metropolitanas. Diante dos resultados, tem-se, evidentemente, seletividade no mercado de trabalho no Brasil metropolitano, sobretudo quando se observa a ocupação segundo o gênero. Em tal cenário, faz-se pertinente propor mais políticas de confirmação do trabalho da mulher.
\end{abstract}

Palavras-chaves: Mercado de Trabalho, Regiões Metropolitanas; Brasil

\begin{abstract}
The political, economic and social configurations of the last decades of the twentieth century and early twenty-first, modified and set new patterns of organization in society over the years. Female participation in the labor market has notified new proposals for consolidation and confirmation of the role of women in the social environment. Therefore, this article has as its central research proposal, to do an analysis of female participation in the labor market in Brazil metropolitan areas. The data are from the National Sample Survey (PNAD) and were analyzed in the cropping that covers the years 2001 and 2008. Key statistics showed the rise of female participation in the labor market with a higher incidence in the Economically Active Population (EAP) in the years under review. In addition, the female unemployment rate decreased in almost all Brazilian metropolitan areas, by raising the occupancy rate. However, they are a minority in the formal labor market, when compared to men, given the high share of employed unregistered. In addition, they are still minorities in occupations of greater social projection, despite a context of increasing in the share over the years. In relation to the occupations of lower social projection they are the majority in all the metropolitan areas. Given the results, there is, of course, selectivity in the labor market in metropolitan áreas in Brazil, especially considering the occupation according to gender. In such scenario, it is appropriate to propose more political confirmation of women's work, with full rights guarantees for them and for those who are exposed to noticeably higher degree of exclusion and the right to equality.
\end{abstract}

Key words: Labor market; Metropolitan areas; Brazil.

\section{Resumen}

Este artículo tiene como objetivo central de la investigación, hacer un análisis de la participación femenina en el mercado laboral en el área metropolitana de Brasil. Los datos provienen de la Encuesta Nacional por Muestra de Domicilios (PNAD) y se analizaron en el cultivo que comprende los años 2001 y 2008. Estadísticas clave mostraron el aumento de la participación femenina en el mercado laboral con una mayor incidencia en la población económicamente activa (PEA) en el año que se examina. Por otra parte, la tasa de desempleo femenino se redujo en casi todas las áreas metropolitanas de Brasil, mediante el aumento de la tasa de ocupación. Sin embargo, son una minoría en el mercado laboral formal, en comparación con los hombres, teniendo en cuenta el alto porcentaje de empleados sin registrar. Además, las minorías siguen en puestos de trabajo con más proyección social, a pesar de un contexto de aumento de la participación relativa en los últimos años. Ya en trabajos de proyección social más baja son más en todas las áreas metropolitanas. Por lo tanto, tenemos, por supuesto, la selectividad en el mercado de trabajo en zonas urbanas del Brasil, teniendo en cuenta especialmente la ocupación por sexo. En tal escenario, es más adecuado proponer políticas confirmación del trabajo de las mujeres.

Palabras clave:: Mercado de trabajo; Áreas metropolitanas; Brasil.

(*) Lecturer, Doctor of the University Regional of Cariri - Rua Cel. Antônio Luiz, 1161, CEP: 63101240, Crato (CE), Brasil. Tel: (+55 88)31021212 - abeleconomia@hotmail.com

(**) Lecturer, Doctor of the University Regional of Cariri - Rua Cel. Antônio Luiz, 1161, CEP: 63101240, Crato (CE), Brasil. Tel: (+55 88) 31021212 - silvanaqueirozce@yahoo.com.br

(***) Lecturer, Doctor of the Federal University of Rio Grande do Norte - Campus Universitário, CEP: 59078-970 - Natal, (RN), Brasil, Tel: (+55 84) 32153836 - clement@ufrnet.br 


\section{INTRODUCTION}

Economic, social, cultural and political transformations experienced by society over the years have caused new configurations in the social environment. The search for the right to equality, driven by the increased participation of women in social decisions and the feminist movement conquest has set new scenario for women of XXI century. The insertion in the labor market, especially in higher social positions projection guide the women's journey in search and consolidation of their role as the political and social transformation agent.

There are concrete records of female participation in the profile of a new age of "equality" in all decision-making centers in the world. However, there are also concrete information that this process continues to exist slowly and with a high degree of rights of inequality within the space in question. In addition, the enthronement of female strength in the labor market is still marked by social and cultural constraints that interfere with the performance of them in their midst.

There are many empirical studies that reported the gain of female participation in the labor market in many specific fields of activity by male action as omnipotent segment agent. They have increased their participation, even in the face of evidence of the existence of double shifts, when you consider that many still perform their activities as mothers and housewives and in some cases the homes are places of work and family life, simultaneously, mainly on the advancement of labor flexibility (Neves \& Pedrosa, 2007; Silva Filho, 2011).

Given this situation, we see that there is strong consolidation of the role of women assuming a more classic function within society: mother and housewife, without, however, dismiss it of new achievements assisted in the new established social order - High professionals quality standards in the labor market, and in all countries. With advancement of women's achievements in the labor market, especially in front of a strong cultural rupture context that ensured that only professional activities in the domestic sphere, have been the observations about the conditions they conquered.

On the one hand, there is the rise of female participation in the labor market in increasing proportions. There are several activities previously targeted by male action that already have high number of posts held by women. On the other, there is empirical records of discrimination, particularly paying them when competing in the labor market, and also highlighted the differences in the same segments, but in the same professions assumed by workers of "collar and tie."

In Brazil, there are empirical studies that prove the rise of female participation in the labor market, especially in professions of strong male segmentation and with a high degree of social projection (Bruschini, 2006; 2007). In addition, there is also a frame of relative improvement in performance indicators in the labor market, with continued reduction in unemployment rates in recent years, although still persist higher rates compared to those experienced by men (Silva Filho, 2011).

Therefore, this article has as its main focus of analysis the labor market in the Brazilian metropolitan areas, especially issues relating to gender and women's performance in the metropolitan context. Therefore, there is still the occupancy classification from socio-occupational categories established to observe the women and their participation in the proposed categories. In addition, it is used the classification method implemented by the Observatory of the Metropolises in order to define such participation occupied by segment.

To achieve the objectives proposed by the study the paper is structured as follows: beyond these initial considerations; in the second section, it is discussed some considerations about the role of women in the labor market over the years; in the third section, it has been implemented the methodological notes for classifying occupations and women's participation in each of them in metropolitan Brazil; in the fourth section, there are some considerations about the labor market and participation of women in recent years; in the fifth section, it's presented the employed population in Brazilian metropolitan regions, with gender distinction for each of the socio-occupational categories; and, lastly, the final considerations are made. 


\section{WOMEN'S PARTICIPATION IN THE LABOR MARKET: ADVANCES AND SETBACKS}

Social changes also assisted in the 1970s allowed the woman several confirmations in their role as social and political agent. The greater participation of feminist movements in decisions and public scale guided the new configurations of women's role in the global scenario. Several achievements were envisioned in the context of interaction between family and work. Even in those years, the increased participation of women in university courses (Bruschini, 2007) signaled that henceforth it would represent the feminine figure in social life.

In addition, demographic changes in the new society postulated prospects of existence of women and traced the women participation patterns in society as harder. Life expectancy at birth for women rose, the average number of children was reduced over the years and the increase of households headed by them have gained significant participation in the Brazilian society (Bruschini, 2007).

Such incidents recorded in Brazilian society from the 1980s to the present day were responsible for the new situation which has delegated the participation of women as social subjects and dismissed the feminine figure of cultural determination established in past times. The women not only devote to domestic work and begin to gain social projection in the economic life with greater participation in the labor market, in political and social decisions debated in many municipal sectors such as health, education, security, among others.

The confirmation of female participation in various social segments and their presence in municipalities segmented by male action draws a new scope for the profession standards and acts as a break pact with the structure defined secularly. Bruschini \& Puppin (2004) show to increase female participation engaged in economic activities of labor segmentation previously dominated by male presence. Women's inclusion in these activities permeates the boundaries of "natural selection" to occupations and modify the previously existing social situation.

Several studies have reported a greater female participation in the labor market as a result of a number of situational factors that enabled such insertion. Among them it is highlighted the necessity to increase the per capita income, modifying the role of women in the social context, with greater interference in political and social life of the country and the emergence of professions with high level of convergence to women's skills (Wajnman \& Perpetual, 1997; Bruschini \& Lombardi, 2000; Leone, 2003; Bruschini, 2006; 2007).

What it should be considered is that according Bruschini \& Puppin (2004), they work in the same professions than men and have lower incomes than them. These notifications have been ratified by Bruschini (2007) and shown to be persistent in the Brazilian labor market in recent years. This allows us to observe the segmented structure in occupations making room for breaking the old occupational environment, without however introducing the right to equality of employed, given the discrepancy, especially salary which persists over time.

The structure of this assisted greater participation of women in professional occupations is related to greater participation of women in the labor market. Additonally it has witnessed a significant increase in the women participation rate in the economically active population, which it is related to both demographic changes experienced in recent years on the need to insert them in the labor market, in many cases, they constitute themselves heads of households. Additionally, there have been cultural configurations that are already determining the greater inclusion of women in the labor market. According to the Bruschini (2007), the inclusion of women in higher education already denotes the professional desire and future prospects of being professional and not just housewives and mothers.

For a lot of women, the insertion difficulties in the labor market may be associated with strong role instituted of housewives and work to reproduce still be inherent to female life in society. They were determined secularly to household tasks and paid work are still challenges in the current social model. In many cases, the labor market and the existence of a paid occupation end up being 
an additional activity for women and constitutes the double shift developed by them in Brazil (Dedecca, 2009).

The growth rates of the economically active female population rise over the years in the Brazilian economy. Beyond the conditions to double work as domestic activities, which for many are also executed, there is still strong resistance to the development of male segmentation activities or many of them in which physical force is crucial to act.

It should also be pointed out that they are more vulnerable to unemployment and the occupation of jobs in the informal economy. As Silva Filho (2011), the National Household Survey data for the series between the years 2001-2008, they are most informal and unemployment in Brazil's metropolitan regions. Additionally, in metropolitan areas of lower economic dynamism these differences are increasing. What deduces greater vulnerability to them, since they are more exposed to unemployment and the occupation of jobs without social protection.

From the above considerations, the following section presents some methodological notes used to analyze women's participation in the Brazilian metropolitan labor market and their classification among the occupations established here.

\section{CONSTRUCTION OF SOCIO-OCCUPATIONAL CATEGORIES}

To define the occupations used in this study were necessary some methodological adjustments based on data from the National Survey by Household Sample Survey - PNAD in relation to occupations defined by the survey, according to the Brazilian Classification of Occupations - CBO. The construction of socio-occupational categories was developed by the Observatory of the Metropolises from the agglomeration of occupations to submit relative similarity and could agglomerate without significant losses for analysis. Thus, there have been certain changes in the categories, so that they could classify them busy in the Brazilian metropolitan areas and allow a comparative analysis between them. The metropolitan areas researched in this study refer to those defined by the Brazilian Institute of Geography and Statistics - IBGE adding the Federal District.

\section{METHODOLOGICAL PROCEDURES RESEARCH}

Initially it's taken some methodological steps from adjustments made in the occupational classification of the Brazilian Institute of Geography and Statistics (IBGE), in 2001, in relation to the Brazilian Classification of Occupations (CBO), 2002-2008. Thus, it became compatible data, allowing yourself to build the socio-occupational categories and compare them among the selected years.

In addition, there have been certain changes, because some code changes of the main activity in 2001 to adapt it to other years. In this sense, the Observatory of the Metropolises used some key variables for the construction of socio-occupational categories, making it restatements necessary for possible comparison between them in the defined period. The years 2001 and 2008 were selected to be part of the first year of the first decade of this century and 2008 was selected because it is the series with less macroeconomics variation and therefore with less effect on the trend of the data. In this case, using 2008 as a final cropping _ was necessary, considering that the National Household Survey is carried out in the penultimate week of September, in which case, Brazil had not yet been hit by the global crisis that year. Only from October Brazil suffers the effects of the crisis and employment rates / unemployment fluctuate with greater variation. Furthermore, this study is the result of research conducted with the Observatory of the Metropolises and thus keeps faithful to the years studied by the team.

During the procedures taken for the construction of socio-occupational categories, from the National Household Survey data (2001-2008), the use of certain key variables was necessary. The Observatory of the Metropolises highlighted: economic sector where people are busy; main economic activity performed in the reference week; position of people in the occupation; age of the 
employed person; occupied sex; schooling in years of study; income and census area. In this case, the metropolitan areas of Belo Horizonte, São Paulo, Rio de Janeiro, Federal District, Fortaleza, Recife and Salvador.

In addition, there have been some necessary changes in the variables, given that they had differences both regarding the conceptual aspects, and in relation to coding. Thus, there was a standardization of these variables developed by the Observatory of the Metropolises, so that it could make a comparative analysis over the years, without compromising the results.

From this, the categories were classified by occupation from the following observations.

\section{CONSTRUCTION OF SOCIO-OCCUPATIONAL CATEGORIES}

On the occupations identified by the National Household Survey, it took 24 groups and ordered the socio-occupational categories covering all occupations. For purposes of this research, it was used the definition of the Observatory of the Metropolises from the reunification of these 24 categories in 8 socio-occupational groups, following the similarity criterion between the professions exercised in the categories. From the foregoing, the Observatory of the Metropolises so discriminated:

- Leaders: they are classified as employers (over 10 workers employed); leaders of the public sector and the private sector. In this case, the leaders of the public sector, the name followed as a criterion to those who had pay less than 20 minimum wages and, in addition, performed their work activities toward occupations. Similar name was assigned to designate the leaders of the private sector, the main filter and Classifying income from the remuneration, as in the previous case, it should be less than 20 minimum wages.

- Small employers: this category was composed only by entrepreneurs who declared to employ in their work activities, up to 10 people, regardless of of economic activity.

- Higher Education Professionals: composed of Autonomous of Higher Education Professional, Employees of Higher Education Professional, Statutories of Higher Education Professional and Higher Education Teachers. In addition, the Observatory of the Metropolises added some indentations in its classification, proposing that the autonomous professionals with college degrees, must exercise their profession in activity that requires higher education, in addition, exercise their profession on their own. With regard to higher education employees, in addition to the mentioned requirements were defined that busy must exercise his labor activity with or without a foraml contract. In relation to statutories of higher education were classified those who develop their activity in the form of a public official, but with income below 20 minimum wages. Regarding Teachers of Higher Education were classified only those who exercise their activities as teachers and have higher education.

Average jobs: consist as the following professions : Offices Occupations - activities in offices, where the occupied one doesn't have management function; Supervisory occupations - composed by those who exercise supervisor and administrator role and don't receive income equal to or greater than 20 minimum wages, even if it is formal or informal; Technical Occupations - exercised by those who have the technical course and training; Occupations of Public Security, Justice and Post - public activities carried out without the need for higher qualifications to the exercise. The Observatory of the Metropolises used also as a filter the exercise in military activities only if, and only if the professionals in this category do not have higher education; Artistic and Similar Jobs - cover only those who are professionally related to the arts, sports and religion. The Observatory adds that, in some cases, there was still filter in relation to the occupation for those who are on the self-employment. 
- Tertiary Workers: are classified those working in trade, formally or informally, or those specialized service providers. With regard to specialized services, it also stands out the need for specific qualifications to perform the activity. There was no filter for the years of the study for this classification.

- Secondary Workers: consist of those who carry out their professional activities in the modern or traditional industry, auxiliaries and construction workers.

- Tertiary Non-Specialized: constitutes this category on the workers in the unskilled service sector, such as domestic, street and handymen. It is not proposed here requiring specific qualifications, either, years of study. He added only as a filter the lack of social protection link in the work of street vendors and handymen.

- Farmers: it consists only of those who manually declared perform their activities in agriculture.

Thanks to the description, the data were tabulated for analysis of metropolitan socio-occupational context of the regions studied.

From the exposure of the methodological procedures, the following section covers some information about gender differences in the Brazilian metropolitan labor market.

\section{LABOUR MARKET AND FEMALE PARTICIPATION IN METROPOLITAN BRAZIL}

It is noted that in Brazil, in recent years, the female population exceeds the male, due to social factors, such as urban violence, responsible for high rates of young male deaths. These diverse results emphasize in Brazilian metropolitan regions. The persistence over the years may be by evidence of the continuity of violent actions in these areas and high records of deaths by accident which is more common on the male population.

The results presented in Figure 1 show that the differences between the sexes in the studied metropolitan areas are less accentuated only in the metropolitan areas of Belo Horizonte and Sao Paulo. But even in the regions of smaller disparities they are still more than 2 percentage points in both 2001 and in 2008. In the Metropolitan Region of Fortaleza have been the greatest records of disparities between the sexes, Population in Active Age - PIA recorded in 2001, 45.7\% of the male population against $54.3 \%$ female.

In 2008, records show inversion of the condition of gender disparities in the Brazilian metropolitan fabric, giving the metropolitan region of Rio de Janeiro the biggest difference between the sexes of PIA, with $46.0 \%$ of men against $54.0 \%$ women in the same year. Furthermore, it is pertinent to point out that the areas of greatest urban violence in the country, these differences also are accentuated, and therefore a phenomenon of social order and not necessarily natural that causes the discrepancy.

Also in figure 1 it can see that in the metropolitan area of Recife, in 2008, 46.3\% of the working age population were male, with a strong presence of female participation in the population density of the area. The main empirical evidence shows that phenomena such as urban violence, traffic accidents, among others, have strong impact on young people and male over the female population. 


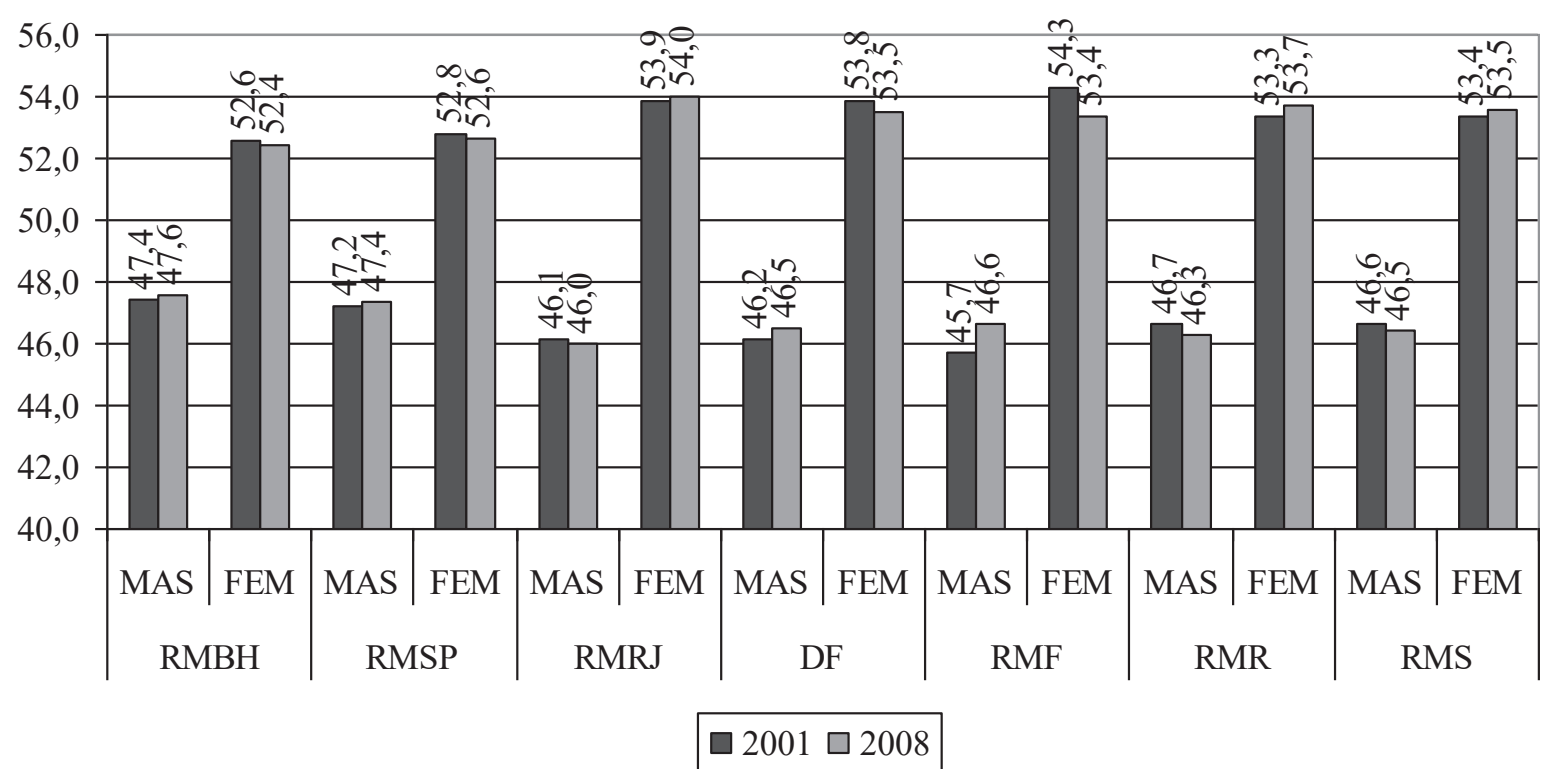

Figure 1 - People of 10 years or older by sex in Brazilian metropolitan regions - 2001/2008 Source: PNAD, 2001 - 2008 / IBGE

Regarding the performance of the labor market, the data of the figure 2 provide information about female participation in the economically active population in Brazil's metropolitan regions. In relation to this performance, only the metropolitan area of Rio de Janeiro and Recife show male EAP records less than $70.0 \%$ of the PIA in both years selected for analysis. The highest rates of participation of the economically active male population were recorded in the metropolitan region of Belo Horizonte, in 2001, (72.7) and the metropolitan areas of Belo Horizonte and Salvador in $2008(72.6 \%)$.

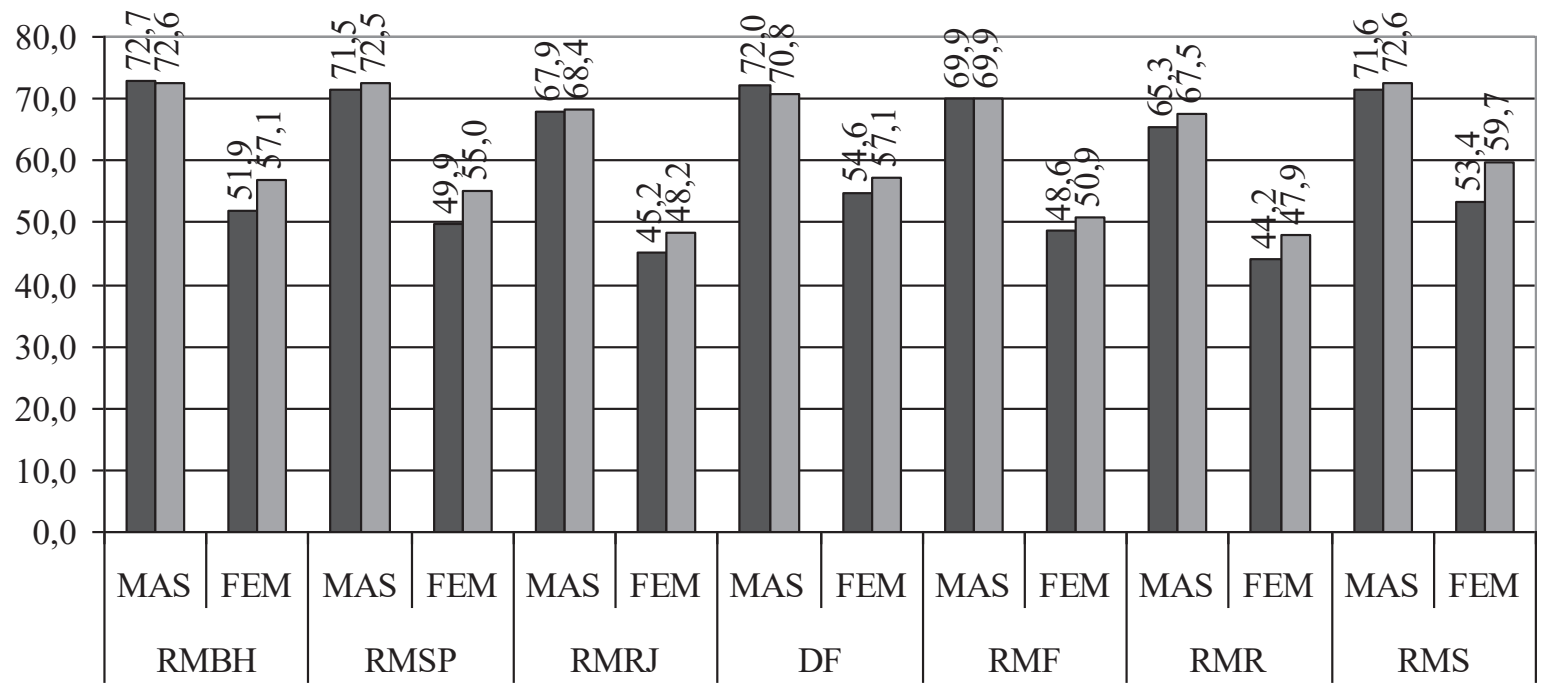

PEA - $2001 \square$ PEA - 2008

Figure 2 - Economically active population by sex in Brazilian metropolitan regions - 2001/2008 Source: PNAD, 2001 - 2008 / IBGE

Moreover, the worst performance was in metropolitan area of Recife in 2001, which recorded only $65.3 \%$ of the male PIA who were economically active in the same year. The low participation rates of economically active in a region may be related to the performance of the labor market, given the economic performance of the region in the period, as well as local socioeconomic conditions 
that can influence the population age elevation to the status of economically active . This time, there can be people delaying entrance into the economically active population because they are in professional training, with exclusively students, or be associated with labor supply conditions in the economy.

With regard to the entry of economically active women in Brazilian metropolitan regions, it must be added the cultural factors that influence positively, by not delimiting the role of women only to the mother state and housewives. Thus, they have increased their participation in the economically active population over the years, in all observed Brazilian metropolitan regions.

In 2001, the metropolitan areas of Belo Horizonte, Federal District and Salvador, it was recorded the highest rates of economically active female participation, with 51.9, 54.6 and 53.4\%, respectively. On the other hand, the lowest female participation rates in the labor force were found in the metropolitan areas of Recife (44.2\%) and Rio de Janeiro (54.2\%) in the same featured year.

In 2008, in all the metropolitan areas the economically active female participation rates increased when compared to 2001. The metropolitan areas of Belo Horizonte and the Federal District showed good performance with $57.1 \%$ of women of working age employed or seeking employment but it was the metropolitan area of Salvador that the highest rate of economically active female participation was seen in 2008. In this one approximately $60.0 \%$ of the female of the economically active population were employed or looking for jobs.

These results confirm the greater insertion of Brazilian women in the labor market. Either by the need to supplement the family income, or by explicit desire to become independent, and cultural issues and rights achievements, the fact is that they are increasingly engaged in conquering spaces before dominated by male population, confirming studies of several authors (Leone, 2003; Arraes et al, 2008;. Silva Filho \& Queiroz, 2009; Silva Filho \& Queiroz, 2010; Leone \& Baltar, 2010).

Thus, even if there is a double shift of female labor, mostly, active women, mothers and housewives still seek the inclusion in the labor market and are conquering professions previously dominated by males (Bruschini, 2007; Hiranta, 2009).

When it refers to the occupancy rate of women in metropolitan areas defined for the study, the data of the figure 3 show that they experience higher unemployment rates when compared to the opposite sex population. For the male population, the data show that in 2001, the highest occupancy rates were recorded in the metropolitan regions of Rio de Janeiro (89.9\%) and Fortaleza (89.6\%). In this last, it was recorded the best female performance in relation to the occupancy rate, with $86.2 \%$ of economically active women employed in the same year. Additionally, the worst performance was for the metropolitan area of Salvador, with record of only $80.9 \%$ of working women. Thus, unemployment reached $19.1 \%$ of them in 2001, which is the highest record established between the metropolitan areas in the screen, followed by the Federal District with $82.2 \%$ occupancy rate.

Also, in 2001, it highlights the good performance for the female labor market in the metropolitan areas of Belo Horizonte, São Paulo and Rio de Janeiro, with 85.1, 84.9 and 84.0\% of economically active women employed, respectively. However, it appears that female unemployment is still sharp when compared to males in metropolitan Brazil. Moreover, even with the highest female enrollment and decrease in fertility rate, women tend to occupy work positions considered as "feminine", with low pay and often without career viability (Borges, 2006).

These differences persist over the years, even in a context of relative improvement to the national labor market, with the good performance of the Brazilian economy, assisted from 2004 (Cintra, 2005; Remy et al, 2012.).

The influences of Brazilian economic growth are visible to the performance of the labor market both male and female. For the male and the female population, only the metropolitan area of Recife attended to accentuate unemployment when comparing 2001 to 2008. At RM, the male employment rate went from 88.4 to 88.1 and female of 82.9 to $80.8 \%$ in 2001 and 2008 , respectively. Thus, it was that most unemployment rate observed for both men and women was recorded in great Recife, with higher incidence for them. 


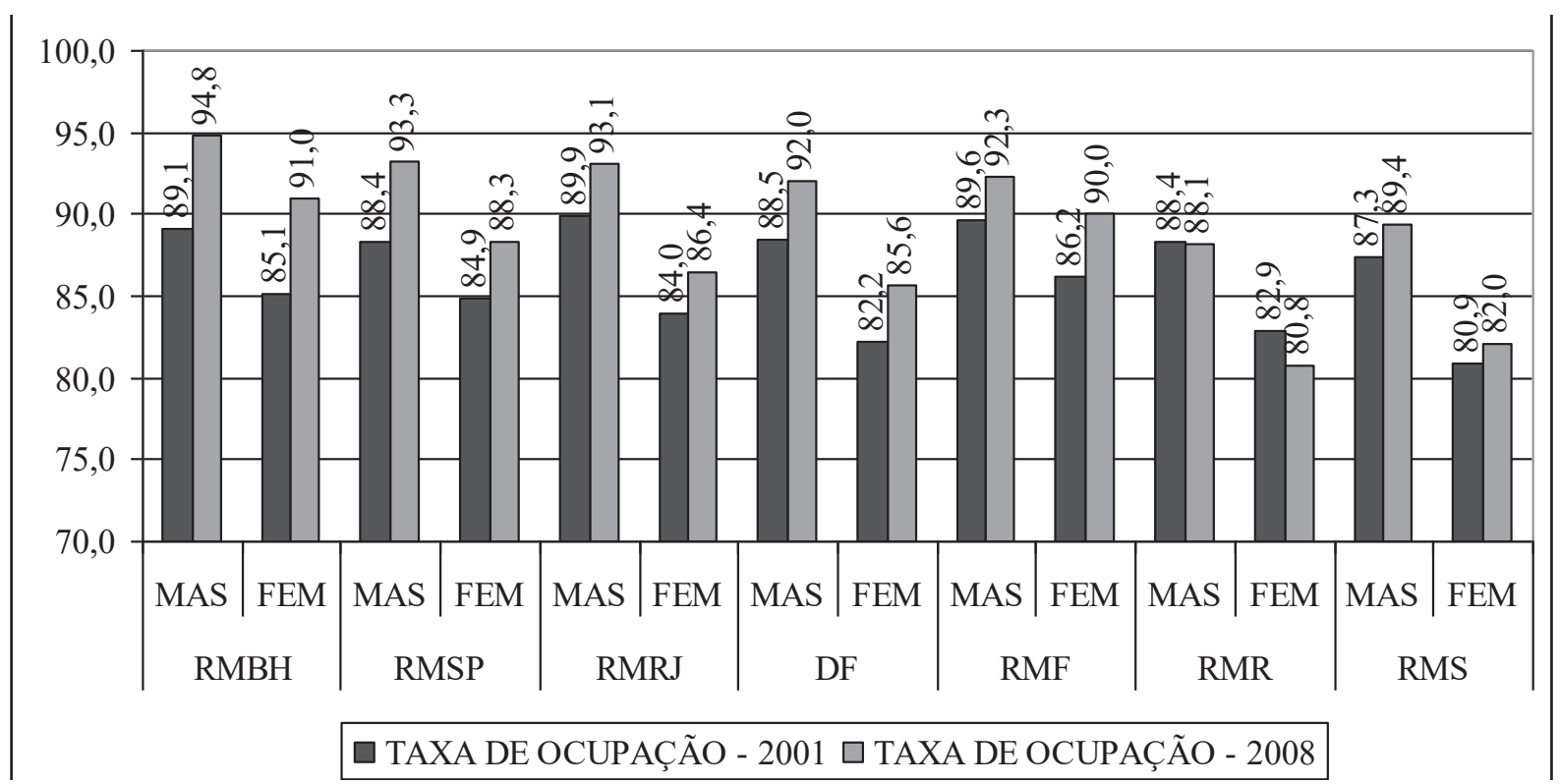

Figure 3 - Occupation rate by sex in Brazilian metropolitan regions - 2001/2008

Source: PNAD, 2001 - 2008 / IBGE

As Lavinas (1996) there are calls active labor policies, but they still have a very limited role and only gradually, are reversing the discrimination between men and women, whether in women entry into the labor market, access to the occupations more social and economic projection and male "niches".

In 2008, the highest occupancy rate for the metropolitan male population was registered in the great Belo Horizonte (94.8\%) followed by the metropolitan regions of São Paulo (93.3\%), Rio de Janeiro (93.1) and Fortaleza (92.3\%). Therefore were these metropolitan regions that witnessed the lowest unemployment rates for males in the same year.

As for the female economically active population, in 2008, the results on the occupancy rate were better than in 2001, except for the metropolitan region of Recife. Women of great Belo Horizonte managed to the highest occupancy rate among the regions under study $(91.0 \%)$, thus, they achieved the lowest unemployment rate $(9.0 \%)$. In the metropolitan area of Fortaleza, the results show the second highest female employment rate $(90.0 \%)$ on a national scale and the best occupancy rate when it comes to the Northeast metropolises. Besides these, the metropolitan regions of São Paulo (88.3\%) and Rio de Janeiro $(86.4 \%)$ showed good performance in relation to female employment rates in 2008.

Even with the sharp decline in female unemployment over the years, it is clear that they are in the labor market with low formality records being greatly lower than those given to male work stations. In figure 4 it can see that the formality in the labor market is shoot between men and women, being smaller this difference in a few analyzed metropolitan areas. In addition, the formality in the labor market is lower in the three metropolitan areas of the Northeast, standing out only the metropolitan area of Salvador, and still lower their degree of formality to the metropolitan areas of the Southeast and Federal District.

Regarding the formality of Brazilian jobs, the data of the figure 4 data show that there are still high informality records in Brazilian metropolitan areas, despite the relative improvement. The national economic dynamics in Brazil, assisted from the mid-2000s, has been responsible for the performance of the national labor market that ensures greater formality rates in the labor market. Empirical studies have shown that the macroeconomic performance of the 2000s corroborated good results for the national indicators, with favorable performance for lifting new jobs covered by the arrangements of the Consolidation of Labor Laws (CLT) (Cintra, 2005; Dedecca \& Rosandiski, 2006; Silva Filho \& Queiroz, 2010; Leone \& Baltar, 2010; Remy et al, 2010). 
In the metropolitan areas focus of this analysis, the results show that between 2001 and 2008 , they experimented to raise the formality rate for the male population. With the exception of the metropolitan regions of Rio de Janeiro and Salvador, the same performance seen for them it was also recorded for the female population. In the metropolitan area of São Paulo, the employed male population in 2001, with protection at work, it was $61.9 \%$ taking the first place in the ranking this year. Moreover, the position is repeated in 2008 when it recorded $67.3 \%$ of employed people with social protection. The worst performance for the male population, both in 2001 and in 2008 was registered in the metropolitan area of Fortaleza, with 41.9 and $46.4 \%$, respectively.

It will be important to highlight that are still high informality rates in Brazil. None of the observed in metropolitan areas could reduce informality in the labor market to $30.0 \%$. There is still strong female participation in the informal sector, and this one accentuated in relation to male. In any year the formality of employed women was higher than the male in the same area of observation. This discrepancy ensures the references presented in regard to the greater participation of women in the informal sector in developing countries (Funkhouser, 1996;. Marcoullier et al, 1997), highlighting the Brazilian labor market and Northeastern (Silva Filho \& Clementino , 2011).

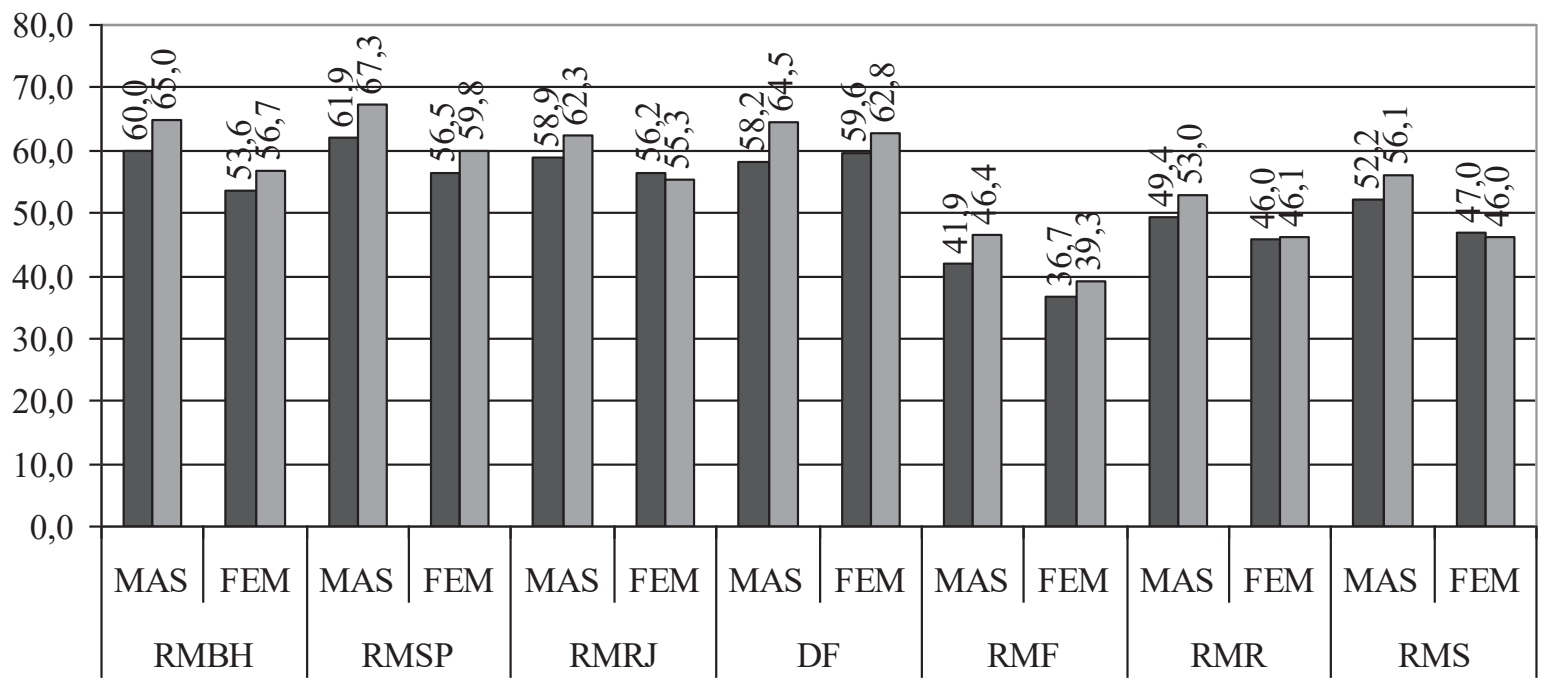

PROTEÇÃO NO TRABALHO - $2001 \square$ PROTEÇÃO NO TRABALHO - 2008

Figure 4 - The protection rate at work by gender in Brazilian metropolitan regions - 2001/2008 Source: PNAD, 2001 - 2008 / IBGE

The biggest formality rates for women were recorded in the Federal District in both years. In the first year it had that $59.8 \%$ of employed women had social protection at work. In 2008, it amounts to the formality of indexes and records up $62.8 \%$ of them with protection. The results observed in this metropolitan area ensure superior performance for women in relation with that observed for men in the metropolitan regions of Rio de Janeiro, Fortaleza, Recife and Salvador. Certainly, the strong participation of employed in government jobs corroborates the result.

The worst performance recorded in the metropolitan area of Fortaleza gave to the occupied women percentage participation less than $40.0 \%$ in the years observed. Thus, more than $60.0 \%$ of employed women worked without reaching the CLT regime. In addition to this metropolitan area, all Northeastern obtained the highest records of informality in female occupations every year. In none of them were registered $50.0 \%$ of employed with social protection at work in any year. This confirms the strong disparity between the Brazilian metropolitan areas, with regard to the dynamics of the labor market and conditions of population occupation.

Therefore, women's entry into the Brazilian metropolitan labor market, especially the Northeast, has no reason to celebrate, they are more qualified, but have higher unemployment. Moreover, 
as Rossini (1988), the women saw at work a solution to the end of the financial dependence on their husbands, where family income was based on the income of men, and it was also a way for companies to pay lower wages, a qualified and disciplined work.

\section{EMPLOYED POPULATION BY SOCIO-OCCUPATIONAL CATEGORY IN BRAZILIAN METROPOLITAN REGIONS}

The classification of socio-occupational categories adopted by the Observatory of the Metropolises suggests, in Table 1, high concentration of busy people in metropolitan Brazil, in segments that allow lower social and financial projection. The data show that in the Leaders category, the relative share is fairly negligible in all Brazilian metropolitan regions. In addition, the Higher Education Professional category, the results are shy in the same areas. There is a strong concentration of busy people in segments of lesser possibility of social mobility, given the low average yield established in these categories (Silva Filho \& Clementino, 2011) and the wide coverage of the labor force employed in the areas under review.

In the category of leaders, in 2001, the metropolitan area of São Paulo and the Federal District have managed the highest rates of participation of employed people (1.4\%). In 2008, it amounts to relative participation in the Federal District $(1.5 \%)$ and that takes the largest share among the regions analyzed. In the metropolitan regions of São Paulo, Rio de Janeiro, Fortaleza, Recife and Salvador, it reduces the relative participation of employed in the above category and only the metropolitan area of Belo Horizonte maintains the same share from one year to another.

Table 1 - Employed population in selected metropolitan areas according to the socio-occupational groups - 2001/2008

\begin{tabular}{|c|c|c|c|c|c|c|c|c|c|c|c|c|c|c|}
\hline \multirow{2}{*}{ Socio-occupational category } & \multicolumn{2}{|c|}{ RMBH } & \multicolumn{2}{|c|}{ RMSP } & \multicolumn{2}{|c|}{ RMRJ } & \multicolumn{2}{|c|}{$\mathrm{DF}$} & \multicolumn{2}{|c|}{ RMF } & \multicolumn{2}{|c|}{ RMR } & \multicolumn{2}{|c|}{ RMS } \\
\hline & 01 & 08 & 01 & 08 & 01 & 08 & 01 & 08 & 01 & 08 & 01 & 08 & 01 & 08 \\
\hline leaders & 0,6 & 0,6 & 1,4 & 0,9 & 0,9 & 0,5 & 1,4 & 1,5 & 0,7 & 0,6 & 0,7 & 0,5 & 0,7 & 0,4 \\
\hline higher education professionals & 5,5 & 7,8 & 6,8 & 8,1 & 7,2 & 10,3 & 9,0 & 12,1 & 5,0 & 5,9 & 6,0 & 6,5 & 4,7 & 6,3 \\
\hline small employers & 3,1 & 2,6 & 2,7 & 2,3 & 2,9 & 2,2 & 2,9 & 2,7 & 2,6 & 2,4 & 2,2 & 2,3 & 2,7 & 1,6 \\
\hline average occupations & 27,1 & 28,1 & 30,2 & 30,2 & 28,8 & 28,6 & 33,2 & 34,0 & 21,4 & 21,5 & 26,1 & 27,2 & 26,8 & $\overline{27,2}$ \\
\hline tertiary workers & 17,7 & 19,0 & 18,6 & 21,0 & 18,9 & 21,0 & 17,9 & 19,0 & 19,6 & 21,0 & 20,4 & 22,2 & 19,7 & 20,9 \\
\hline secondary workers & 22,7 & 22,3 & 22,5 & 22,2 & 19,3 & 19,3 & 13,8 & 11,7 & 23,7 & 25,3 & 18,5 & 17,8 & 20,2 & $\overline{19,6}$ \\
\hline $\begin{array}{l}\text { Workers from non-specialized } \\
\text { tertiary }\end{array}$ & 19,4 & 16,9 & 17,2 & 14,7 & 21,3 & 17,4 & 20,5 & 17,7 & 21,9 & 20,4 & 23,1 & 21,8 & 23,4 & 22 \\
\hline farmers & 3,8 & 2,7 & 0,7 & 0,6 & 0,8 & 0,7 & 1,4 & 1,2 & 5,0 & 2,9 & 3,0 & 1,8 & 1,7 & $\overline{1,2}$ \\
\hline Total & 100 & 100 & 100 & 100 & 100 & 100 & 100 & 100 & 100 & 100 & 100 & 100 & 100 & 100 \\
\hline
\end{tabular}

Source: PNAD, 2001 - 2008 / IBGE

In the category of Higher Education Professionals, it registered elevated the participation of employed in all the metropolitan areas . However, the best results were in the Federal District both in $2001(9.0 \%)$ as in $2008(12.1 \%)$. In contrast, the metropolitan area of Salvador had the lowest relative share in 2001 (4.7\%) and in the great Fortaleza in 2008 (5.9\%). So in the Northeast metropolitan areas were registered the lowest rates of busy people in this category in 2008, pointing to the permanence of the 'gap' between the cities of the Northeast and the rest of the country.

The category called Small Employers presented a contrary tendency regarding to the previously one presented as only the metropolitan area of Recife attended to raise the share of employed from one year to the next, unlike other areas that have reduced. In 2001, the largest share was recorded in the metropolitan area of Belo Horizonte (3.1\%) and the lowest in the great Recife $(2.2 \%)$. In 2008 , the highest occupancy rate was recorded in the Federal District $(2.7 \%)$ and the lowest in the great Salvador (1.6\%). 
In the Averages Occupations the results show high share of employed in the Federal District and in the metropolitan region of São Paulo, both in 2001 and in 2008. But it was in the Federal District who registered more than $33.0 \%$ in the first and $34.0 \%$ in second year, of the busy people acting in this category. In the metropolitan area of São Paulo, the share was the same in both years $(30.2 \%)$. In this category, the metropolitan area of Fortaleza achieved the lowest rate of participation. In the metropolitan areas of Belo Horizonte, Recife and Salvador were registered rise in the participation rate of employed in the years exposed.

In addition to the Averages Occupations shown above, the data show strong concentration of of the busy people in the Tertiary in all Brazilian metropolitan regions. But it was in the great Recife which there have been the highest percentages in this segment. In 2001, there was $20.4 \%$ of employed, rising up in 2008, to $22.2 \%$. On the other hand, in 2001, the lowest percentage shares were recorded in the great Belo Horizonte and the Federal District, with 17.7 and 17.9\%, respectively.

In Secondary Workers category the records show high concentration of busy people in metropolitan areas under analysis. Smaller participations were found in the Federal District, both in $2001(13.8 \%)$ as in $2008(11.7 \%)$. In this area there is no predominance of the industrial sector as a generator of jobs, and therefore it's justified the low participation that enormously distances from the others. On the other hand the metropolitan area of Fortaleza, with a strong concentration of industrial textiles and footwear, intensive segments of labor, achieved the largest share of employed in the sector both in 2001 (23.7\%) as in 2008 (25.3\%). In addition to this, the metropolitan regions of São Paulo and Belo Horizonte, also showed high percentages of employed people in this category, distancing themselves from the others.

The data Non-Specialised Tertiary show that there was a reduction in the share of employed persons in this category in all Brazilian metropolitan regions. However, the metropolitan areas of Fortaleza, Recife and Salvador (all in the Northeast) have managed more than $20.0 \%$ of their employed labor force in this sector in the years under study. The regional economic dynamics, without a doubt, contributes to the results and shows that the areas most vulnerable to worst work stations are those with lower levels of economic development. Besides, it is still stood out the low percentages recorded in the agricultural sector and reducing of the relative share in all the metropolitan areas.

Regarding the sex of occupied by each of the defined socio-occupational categories and in each of the metropolitan areas, the data data of the Table 2 show convergent results of the discussions presented in previous sections. Regarding the Leaders category, the results in 2001 show that there is still an absolute majority of employed males. The smallest gap was observed in the Federal District, where $67.2 \%$ of the employed were males against $32.8 \%$ female. The great Salvador showed the highest distinction of employed in the category, with $86.4 \%$ of employed men against $13.6 \%$ female in the same year, it shows that even before the results observed by Bruschini \& Pupin (2004), still there is still high incidence of male professionals leading the occupations with better working conditions.

In 2008, the smallest difference between the sexes of the occupied was taken over by the metropolitan area of Recife (67.7\% of male and occupied $32.3 \%$ of female employees) - even with high participation of men engaged in this category 20012008 - and the Federal District raises the differences previously noted registering the second largest discrepancy observed $(23.7 \%$ of men against $26.3 \%$ of employed women as leaders), behind only the great Belo Horizonte which obtained $74.3 \%$ of employed male against $25.7 \%$ female. Even if is found a greater relative share of employed women as leaders in Brazilian metropolitan areas (except the Federal District and the great Recife that reduced), the data reveal a strong concentration of male busy in this category, being it the best social projection here established.

In Higher Education Professionals category women were the majority in all the metropolitan areas observed both in 2001 as in 2008. It should be noted that it was in the Fortaleza metropolitan area that recorded the greatest disparity between occupied by sex. In the year of 2001 only $39.2 \%$ of 
the employed in the above category were male. The smallest gender gap of employed was observed in the metropolitan area of Rio de Janeiro in the same year (46.4\% of employed men against $53.6 \%$ of women). In 2008, it amounts the male participation of employed people in this category in the metropolitan areas of Belo Horizonte, São Paulo, Federal District and Salvador. In the metropolitan regions of Rio de Janeiro, Fortaleza and Recife in the year 2001 the differences are more accentuated, and increases the participation of employed women in the category.

Table 2 - Employed population by gender in the metropolitan areas selected according to socio-occupational groups - 2001/2008

\begin{tabular}{|c|c|c|c|c|c|c|c|c|c|c|c|c|c|c|}
\hline \multirow{3}{*}{ Socio-occupational category } & \multicolumn{2}{|c|}{ RMBH } & \multicolumn{2}{|c|}{ RMSP } & \multicolumn{2}{|c|}{ RMRJ } & \multicolumn{2}{|c|}{$\mathrm{DF}$} & \multicolumn{2}{|c|}{ RMF } & \multicolumn{2}{|c|}{ RMR } & \multicolumn{2}{|c|}{ RMS } \\
\hline & \multicolumn{2}{|c|}{2001} & \multicolumn{2}{|c|}{2001} & \multicolumn{2}{|c|}{2001} & \multicolumn{2}{|c|}{2001} & \multicolumn{2}{|c|}{2001} & \multicolumn{2}{|c|}{2001} & \multicolumn{2}{|c|}{2001} \\
\hline & M & $\mathrm{F}$ & M & $\mathrm{F}$ & M & $\mathrm{F}$ & M & $\mathrm{F}$ & M & $\mathrm{F}$ & M & $\mathrm{F}$ & M & $\mathrm{F}$ \\
\hline leaders & 81,8 & 18,2 & 79,7 & 20,3 & 73,8 & 26,2 & 67,2 & 32,8 & 76,2 & 23,8 & 62,8 & 37,2 & 86,4 & 13,6 \\
\hline higher education professionals & 41,0 & 59,0 & 42,2 & 57,8 & 46,4 & 53,6 & 46,0 & 54,0 & 39,2 & 60,8 & 44,4 & 55,6 & 45,4 & 54,6 \\
\hline small employers & 71,5 & 28,5 & 69,4 & 30,6 & 70,2 & 29,8 & 69,5 & 30,5 & 75,0 & 25,0 & 59,5 & 40,5 & 71,0 & 29,0 \\
\hline average occupations & 55,7 & 44,3 & 53,9 & 46,1 & 58,4 & 41,6 & 54,2 & 45,8 & 54,7 & 45,3 & 57,7 & 42,3 & 55,0 & 45,0 \\
\hline tertiary workers & 47,9 & 52,1 & 53,3 & 46,7 & 50,4 & 49,6 & 49,7 & 50,3 & 48,1 & 51,9 & 47,4 & 52,6 & 43,7 & 56,3 \\
\hline secondary workers & 86,6 & 13,4 & 81,1 & 18,9 & 85,0 & 15,0 & 90,0 & 10,0 & 69,2 & 30,8 & 88,2 & 11,8 & 87,8 & 12,2 \\
\hline $\begin{array}{c}\text { Workers from non-specialized } \\
\text { tertiary }\end{array}$ & 35,9 & 64,1 & 35,4 & 64,6 & 39,1 & 60,9 & 36,1 & 63,9 & 42,7 & 57,3 & 44,4 & 55,6 & 38,0 & 62,0 \\
\hline farmers & 43,7 & 56,3 & 58,1 & 41,9 & 80,4 & 19,6 & 76,3 & 23,7 & 73,1 & 26,9 & 69,7 & 30,3 & 63,1 & 36,9 \\
\hline Year & \multicolumn{2}{|c|}{2008} & \multicolumn{2}{|c|}{2008} & \multicolumn{2}{|c|}{2008} & \multicolumn{2}{|c|}{2008} & \multicolumn{2}{|c|}{2008} & \multicolumn{2}{|c|}{2008} & \multicolumn{2}{|c|}{2008} \\
\hline leaders & 74,3 & 25,7 & 71,8 & 28,2 & 69,0 & 31,0 & 73,7 & 26,3 & 71,1 & 28,9 & 67,7 & 32,3 & 69,0 & 31,0 \\
\hline higher education professionals & 43,9 & 56,1 & 45,8 & 54,2 & 44,7 & 55,3 & 47,5 & 52,5 & 38,9 & 61,1 & 37,4 & 62,6 & 46,3 & 53,7 \\
\hline small employers & 68,5 & 31,5 & 67,4 & 32,6 & 58,8 & 41,2 & 62,9 & 37,1 & 59,2 & 40,8 & 70,0 & 30,0 & 57,0 & 43,0 \\
\hline average occupations & 52,0 & 48,0 & 54,0 & 46,0 & 56,5 & 43,5 & 54,3 & 45,7 & 52,4 & 47,6 & 55,0 & 45,0 & 50,6 & 49,4 \\
\hline tertiary workers & 41,3 & 58,7 & 43,9 & 56,1 & 47,0 & 53,0 & 45,2 & 54,8 & 49,0 & 51,0 & 44,9 & 55,1 & 42,9 & 57,1 \\
\hline secondary workers & 88,3 & 11,7 & 82,3 & 17,7 & 87,4 & 12,6 & 90,6 & 9,4 & 70,0 & 30,0 & 88,0 & 12,0 & 88,9 & 11,1 \\
\hline $\begin{array}{c}\text { Workers from non-specialized } \\
\text { tertiary }\end{array}$ & 30,1 & 69,9 & 35,9 & 64,1 & 37,9 & 62,1 & 36,1 & 63,9 & 46,5 & 53,5 & 46,5 & 53,5 & 35,9 & 64,1 \\
\hline farmers & 43,1 & 56,9 & 64,8 & 35,2 & 71,7 & 28,3 & 64,1 & 35,9 & 63,9 & 36,1 & 80,7 & 19,3 & 51,2 & 48,8 \\
\hline
\end{tabular}

Source: PNAD, 2001 - 2008 / IBGE

Therefore, despite the women possess higher level of education, they have higher rates of unemployment and take jobs with less social and financial projection, persisting inequality in the Brazilian metropolitan labor market. On the other hand, even living with discrimination, they seek to qualify to be inserted in the universities, and their presence noticed in Brazilian society (Bruschini \& Lombardi, 2000).

Regarding the Small Employers it realizes that there were significant variations in some of the metropolitan areas analyzed. However, it is noteworthy that in all the years and all the metropolitan areas the men were most occupied in the category. What has been observed was the significant reduction of male participation occupied in metropolitan areas of Rio de Janeiro, Fortaleza and Salvador which were 70.2, 75.0 and $71.0 \%$ in 2001, dropping to 58.8, 59.2 and $57.0 \%$ in 2008 , respectively. In the metropolitan area of Recife the dynamics was opposite when the male participation occupied in the category out of $59.5 \% 2001$ to $70.0 \%$ in 2008 . Thus, it has, that was in that socio- occupational category that recorded the biggest swings from one year to another.

In the tertiary were registered the smallest gap in respect to the sex of the occupied. In this category the women were occupied majorities In the metropolitan regions of Belo Horizonte, Distrito Federal, Fortaleza, Recife and Salvador, with the largest difference recorded in the great Salvador with $43.7 \%$ of men against $56.3 \%$ of women employed in the year 2001 . In the greater São Paulo 
and Rio de Janeiro men were most occupied in the same year. In 2008, women form the majority in all the metropolitan areas with the lowest recorded discrepancy in the great Fortaleza, with 51.0\% of employed women against $49.0 \%$ of men.

Thus, women in the Brazilian metropolitan labor market, continue to be inserted in traditional sectors such as services and trade. But according Vieceli (2011), gradually, they stand out in activities related to trade and repair and also in public administration generally pay better.

In the category of secondary workers, both in 2001 and in 2008, employed men were absolute majority in all the metropolitan areas analyzed. The largest differences were observed in the metropolitan areas of the Federal District, Fortaleza and Recife, with 90.0, 88.2 and 87.8\% of occupied men, respectively. In 2008, amounts to participation of men engaged in all the metropolitan areas, with the exception of large reef that showed a slight percentage reduction. Therefore, it has been in the industry that men are still the majority in the occupation of jobs and with strong relative share in all the observed years.

In this context, the men remain showing higher income in the industrial work face to face with women, confirming this economic sector as a "niche" male, and revealing that the Brazilian metropolitan labor market remains segmented, given the major chances of better jobs for men.

In the Non-Specialised Tertiary the occupied female stand out in all the metropolitan areas both in 2001 as in 2008. The highest male participation in the occupational category was recorded in 2001, in the great Recife (44.4\%). In 2008, men occupied 46.5\% in the metropolitan areas of Fortaleza and Recife, which were the highest male employment rates in this category in that year. It also points out that the female participation increased in the category in the metropolitan areas of Belo Horizonte, Rio de Janeiro and Salvador, and reduced in the great São Paulo, Fortaleza and Recife, keeping constant the female participation in the Federal District.

In the condition of farmers the data show that only in the metropolitan region of Belo Horizonte women were most occupied much in 2001 as in 2008. In the other metropolitan areas the men took the largest share, and the metropolitan of Rio de Janeiro in 2001, (80.4\%) and Recife in 2008 (80.7\%) male participation was greater than $80.0 \%$ of the work positions of the aforementioned segment.

These results show that despite the expansion of the professional range of women in metropolitan Brazil, they are mostly in non-specialized tertiary and on condition of farmers. Therefore, the increase in female educational field has not yet been felt in occupations and income. Thus, women continue to be the key in some traditional sectors such as the tertiary sector and social activities.

\section{FINAL CONSIDERATIONS}

This article aimed to analyze the Brazilian metropolitan labor market and its interaction between the sexes and occupations defined here. The main results show that women are majorities of working age in all areas of analysis. Social and demographic factors corroborated for greater female participation in detriment of the men in metropolitan Brazil.

In relation to the economically active population, the data show relative increase in women's participation in all the observed years. Factors such as greater desire for financial independence, complementation of the family income, sharp decline in fertility rates, and higher education, as well as search for the desired equality between men and women, make them social subjects of great commitment to the actions of interaction between work and society over the years. The search for work or the realization of the desire for financial independence, shows that female labor force grows in Brazil metropolitan recently.

However, it is pertinent to point out that they experience the highest rates of unemployment when compared to men. This was verified in all the metropolitan areas, even before a performance that notified relative reduction of female unemployment rates when compared to the year 2001 to 2008. In addition, female unemployment is more accentuated in the metropolitan areas of the Nor- 
theast, where there is strong cultural resistance to the role of women in society and the labor market, especially in sectors in which they operate the male labor more easily and / or greater integration, such as construction and transportation sector.

It is noticeable that occupied bwomen in Brazilian metropolitan regions experience greater informality rates than men. This phenomenon also is accentuated in the northeastern metropolitan areas at the expense of others, given that they are employed in occupations that hire more informal, and thus absent from social protection at work.

In the Northeastern metropolitan areas, according to the data analyzed, more than $50.0 \%$ of employed women work without social protection offered by CLT. However, it is worth noting that informality is high for both sexes and in all areas studied here, being more pronounced for women and Northeast.

With regard to occupation, there is low participation of employed people in the socio-occupational categories that allow greater social and economic projection, which showed tendency to reduce over the years, in almost all regions increase in the share of employed compared to two years in study.

When analyzing the occupations according to sex, there is greater male participation in the best opportunities occupations, and greater participation of women in occupations traditionally recognized as low-quality, intensive workforce and which pay low salaries, especially in service segments. Therefore, during the first decade of the 2000s, despite a context of relative rise of female participation in higher social support occupations, they are significant minorities in these categories and remain greatly occupying the basic categories.

Given the above, there is still much to do for the right to gender equality, especially in the Brazilian metropolitan labor market. It takes public policy with emphasis on promoting jobs with female skills and social relevance. It is proposed even better job opportunities in male-targeted areas, so that they can enjoy the benefits of working with greater social and financial recognition, and greater possibilities of reducing culturally implemented inequality in Brazilian society, in which women, even being more educated than men and earn the lowest incomes, to reach their homes, most often, they have a double day, after a long day of work.

So even before the picture of relative improvement in women's participation in the Brazilian metropolitan labor market, it is not enough to ensure the rupture of a solidified system that define the roles of men and women, and keeps them under the protection of a fragmented job and low empowerment. Therefore, to think collective actions in the labor market and offer greater female participation in occupations of greater social and financial projection is to ensure the right to equality so desired by women, and that is, in most cases, in just writing the passages of the Constitution of 1988.

In brief, it is necessary that women take their place in society and in the Brazilian labor market, "drop" all the barriers that impedes gender equality by imposing all your needs, showing that they are essential to the economy and the social development of the country.

\section{BIBLIOGRAPHIC REFERENCE}

ARRAES, A. K. M.; QUEIROZ, S. N.; ALVES, C. L. B.. Mercado de trabalho formal na indústria: comparativo entre as regiões Nordeste e Sudeste nos anos de 1994 e 2004. II Encontro Internacional Trabalho e Formação de Trabalhadores. Anais... Fortaleza: LABOR/UFC, 2008.

BORGES, Â. Desemprego e precarização em Regiões Metropolitanas: um olhar a partir das famílias. Análise sobre a Pesquisa Nacional por Amostra de Domicílios (PNAD 2004. (Edição Especial). Bahia, Parcerias estratégicas - n. 22, 2006.

BRUSCHINI, C.; LOMBARDI, M. R. A Bipolaridade do trabalho feminino no Brasil contemporâneo. Cadernos de Pesquisa, n.110, p.67-104, jul. 2000. 
BRUSCHINI, C.; PUPPIN, A. B. Trabalho de mulheres executivas no Brasil no final do século XX. Cadernos de Pesquisa, v.34, n.121, p.105-138, jan./abr. 2004.

BRUSCHINI, M. C. A.. Trabalho e gênero no Brasil nos último dez anos. Cadernos de Pesquisa, v. 37, $\mathrm{n}^{\circ}$ 132, p. 537-572. Set/dez, 2007.

BRUSCHINI, M. C. A..Trabalho doméstico: inatividade econômica ou trabalho não remunerado? Revista Brasileira de Estudos de População, v.24, n. esp., 2006.

CINTRA, M. A. M.. Suave Fracasso - a política macroeconômica brasileira entre 1999 e 2005. Revista Novos Estudos, novembro de 2005.

DEDECCA, C. S.; ROSANDISKI, E. N.. Recuperação econômica e geração de empregos formais. Revista Parcerias Estratégicas - Número 22- Junho 2006.

DEDECCA, C. S.. Regime de Trabalho uso de Tempo e Desigualdade entre Homens e Mulheres. In: http// www.fcc.org.br/seminario/DEDECCA.pdf. Acesso em outubro de 2009.

FUNKHOUSER, E.. The urban informal-sector in Central America: Household survey evidence. World Development, v. 24, nº 11, p. 1.737-1.751, 1996.

GONÇALVES, M. E.; PEREZ, E. R.; WAJNMAN, S. taxas de participação (formal e informal) feminina no mercado de trabalho das regiões Sudeste e Nordeste: uma análise a partir das PNAD's, 1992-2002. XIV Encontro nacional de Estudos Populacionais - ABEP. Anais... Caxambú-MG, setembro de 2004.

HIRATA, H.. A precarização e a divisão internacional e sexual do trabalho. Revista Sociologias, Porto Alegre, ano 11, no 21, jan./jun. 2009, p. 24-41.

LAVINAS, L. Aumentando a competitividade das mulheres no mercado de trabalho. Revista Estudos Feministas, CIEC - Rio de Janeiro, v. 4, n.1, p. 171-183, 1996.

LEONE, E.T. 2003. O trabalho da mulher em Regiões Metropolitanas Brasileiras. In: M.W. PRONI; W. HENRIQUE (orgs.). Trabalho, mercado e sociedade: o Brasil nos anos 90. São Paulo, Editora UNESP; Campinas, SP, Instituto de Economia da UNICAMP, p. 199-230.

LEONE, E. T.; BALTAR, P. E. de A.. População ativa, mercado de trabalho e gênero na retomada do crescimento econômico. Encontro Nacional da Associação Brasileira de Estudos Populacionais, 17., 2010, Caxambu. Anais... Caxambu: ABEP, 2010.

MARCOULLIER, D.; RUIZ de CASTILLA, V.; WOODRUFF, C.. Formal measures of the informal-sector wage gap in Mexico, El Salvador and Peru. Economic development and cultural change, v. 45, $\mathrm{n}^{\circ} 2$, $\mathrm{p}$. 367-392, 1997.

NEVES, M. de A.; PEDROSA, C. M.. Gênero, flexibilidade e precarização: o trabalho a domicilio na indústria de confecções. Sociedade e Estado, Brasília, v. 22, Nº 1, p. 11-34, Jan/ABR, 2007.

REMY, M. A. P. de A.; QUEIROZ, S. N. de; SILVA FILHO, L. A.. Evolução Recente do Emprego Formal no Brasil - 2000-2008. Revista da ABET...

ROSSINI, R. E. Geografia e Gênero: a mulher na lavoura canavieira paulista. Tese de Livre Docência. São Paulo: USP, 1988.

SILVA FILHO, L. A.; QUEIROZ, S. N. de.. A trajetória da Indústria e do Emprego formal no Ceará 1996/2006. XI Encontro Nacional de Estudos do Trabalho (ABET). Anais... Campinas - SP, 2009.

SILVA FILHO, L. A.. Reestruturação produtiva e desestruturação no mercado de trabalho: análise empírica da indústria têxtil da grande Natal. Anais do XVII Encontro Nacional da Associação Brasileira de Estudos Populacionais - ABEP. Anais... Caxambú - MG, setembro, 2010.

SILVA FILHO, L. A.; QUEIROZ, S. N. de.. Recuperação econômica e emprego formal: avaliação empírica para o Nordeste brasileiro -2000/2008. Revista Perspectiva Econômica, vol. 7, N.1, p. 42-54, jan/jun 2011. SILVA FILHO, L. A. Mercado de Trabalho e Estrutura Sócio-ocupacional: estudo comparativo entre as regiões metropolitanas de Fortaleza, Recife e Salvador - 2001-2008. Dissertação de Mestrado em Economia. Universidade Federal do Rio Grande do Norte, 2011, 131 p.

SILVA FILHO, L. A.; CLEMENTINO, M do L. M.. Considerações sobre o perfil sócio-ocupacional nas regiões metropolitanas do Nordeste - 2001/2008. XII Encontro Nacional de Estudos do Trabalho (ABET). Anais... João Pessoa - PB, 2011. 
VIECELI, Cristina Pereira. Mulher e trabalho no Brasil: características, avanços e permanências (19602009). Porto Alegre, 2011.

WAJNMAN, S. PERPÉTUO, I.H. A redução do emprego formal e a participação feminina no mercado de trabalho brasileiro. Nova Economia, Belo Horizonte, v.7, n.1, 1997

Submitted april 2016

Accepted may 2016 
SILVA FILHO, L. A.; QUEIROZ, S. N.; CLEMENTINO, M. L. M. 